\title{
A case study of lean, sustainable manufacturing
}

\author{
Geoff Miller ${ }^{1}$, Janice Pawloski ${ }^{2}$, Charles Standridge ${ }^{3}$ \\ ${ }^{1}$ Grand Rapids Chair Company (USA); ${ }^{2,3}$ School of Engineering, Grand Valley State University \\ (USA) \\ geoff@grandrapidschair.com; pawloskj@gusu.edu; standrio@gvsu.edu
}

Received December 2009

Accepted May 2010

\begin{abstract}
A small furniture production company has integrated lean tools and sustainability concepts with discrete event simulation modeling and analysis as well as mathematical optimization to make a positive impact on the environment, society and its own financial success. The principles of lean manufacturing that aid in the elimination of waste have helped the company meet ever increasing customer demands while preserving valuable resources for future generations. The implementation of lean and sustainable manufacturing was aided by the use of discrete event simulation and optimization to overcome deficits in lean's traditional implementation strategies. Lean and green manufacturing can have a more significant, positive impact on multiple measures of operational performance when implemented concurrently rather than separately. These ideas are demonstrated by three applications.
\end{abstract}

Keywords: lean manufacturing, green manufacturing, case-study, discrete event simulation, optimization

\section{Introduction}

Manufacturers are under tremendous pressure to improve productivity and quality while reducing costs. This has led many organizations to implement the Toyota Production System (TPS), otherwise known as lean manufacturing (Liker, 2004; Womack, 2003). Thus, it seems to be important to gain an understanding of how TPS relates to other methods for improving manufacturing systems including Green 
Manufacturing and quantitative analysis performed using tools such as mathematical optimization and discrete event simulation. In this regard, validation evidence for two premises is sought through a case study at a small furniture production company.

- TPS (Lean Manufacturing) transcends Green Manufacturing, that is, a lean transformation of a production facility will likely result in a green transformation as well.

- The application of quantitative analysis tools such as mathematical optimization and discrete event simulation makes a lean transformation more precise and thus leaner.

\section{Background of lean and green manufacturing}

Founded in post-WWII Japan by Sakichi Toyoda and chief engineer Taiichi Ohno, TPS is largely grounded in the systematic elimination of what Toyota identified as the eight deadly wastes. TPS uses several different tools to strategically align not only their production facilities but their supplier's facilities in the elimination process of these wastes (Bergmiller and McWright, 2009) as seen in Table 1.

\begin{tabular}{|l|l|}
\hline Form & Description \\
\hline Overproduction & Producing more than is needed and/or used. \\
\hline Human Resources & Not using people's minds and getting them involved. \\
\hline Transportation & Moving tools/materials to the point of use. \\
\hline Inventory & Materials or information. Includes WIP and Finished goods. \\
\hline Motion & Movement of people (walking, riding) as well as smaller movements. \\
\hline Corrections & This includes rework or fixing of products. \\
\hline Over-Processing & Additional work above the requirements and/or needs. \\
\hline Waiting & Time delays for materials, information or people. \\
\hline
\end{tabular}

Table1. "Eight forms of waste identified by Toyota".

The connection between lean and green manufacturing has been well documented in recent literature (Angel, Klassen, 1999; Sawhney, Teparakul, Aruna and Li, 2007). Green, or sustainable, manufacturing is defined by Allwood (2009) as a method to "develop technologies to transform materials without emission of greenhouse gases, use of non-renewable or toxic materials or generation of waste". The term "green", often used interchangeably with "environmentally-safe", comes from ideology that was originally developed by the Green Party, a political party in Australia in the early 1970's whose political agenda quickly spread around the world. Their name has been assimilated into the North American vernacular 
(History of the Green Movement, 2009). Notably, the green wastes are very different from the lean wastes. Lean seeks to eliminate traditional production objectives like cost or time (Bergman, Hermann, Stehr, \& Sebastian, 2007) while green is concerned with wastes that impact the environment as seen in Table 2 (Bergmiller \& McWright, 2009).

\begin{tabular}{|l|l|}
\hline Concept & Description \\
\hline Permit Compliance & Compliance with applicable permits. \\
\hline Toxic Release Inventory (TRI) & Over 300 chemicals subject to release. \\
\hline $33 / 50$ Chemicals & $\begin{array}{l}\text { A subset of TRI chemicals identified by the EPA as priority candidates } \\
\text { for voluntary reductions by industry. }\end{array}$ \\
\hline Clean Air Act Toxics & 189 chemicals listed in the Clean Air Act as air toxics. \\
\hline Risk-Weighted Releases & Toxic chemicals weighted by their relative toxicity. \\
\hline Waste Per Unit of Production & $\begin{array}{l}\text { Percentage of production lost as waste, generally measured by } \\
\text { weight. }\end{array}$ \\
\hline Energy Use & $\begin{array}{l}\text { Total energy use by all aspects of corporate operations; also } \\
\text { expressed as carbon dioxide. }\end{array}$ \\
\hline Solid Waste Generations & Total solid waste going to landfills or other disposal facilities. \\
\hline Product Life Cycle & $\begin{array}{l}\text { The total impact of a product on the environment from raw materials } \\
\text { sourcing to ultimate disposal. }\end{array}$ \\
\hline
\end{tabular}

Table 2. "Nine forms of waste identified by green manufacturing".

Bergmiller and McWright (2009) identified manufacturing firms who had implemented lean manufacturing and received one of lean's most distinguished awards, the Shingo Prize (The Shingo Prize for Operational Excellence, 2009). He found that these firms were significantly greener than a general population of other manufacturers in twenty five of twenty-six measures of green manufacturing. Bergmiller and McWright utilized an online survey tool in order to harvest information from Shingo award-winning manufacturers. The survey was divided into three sections, as follows:

- Status of their plant(s) environmental management system (EMS)

- Fourteen questions regarding the application of environmental waste techniques at the plant(s)

- Ten questions about advantages/ disadvantages of the EMS at the plant(s)

The survey results identified and validated a strong correlation between the successful development and implementation of lean to the "greenness" of a manufacturer. He stated that "lean seemed to transcend green". Also, he identified that the surveyed companies tended to strategically vertically integrate versus 
horizontally integrate their plant(s). The vertical integration led to reductions in many of the green wastes found in Table 2.

Sawhney, Teparakul, Aruna, and Li (2007) show the connection between lean manufacturing and the environmental movement stating that "it is natural that the lean concept, its inherent value-stream view and its focus on the systematic elimination of waste, fits with the overall strategy of protecting the environment", which they call Environmental Lean (En-Lean). A focus group of environmental and lean professionals compared the environmental impact of a cellular manufacturing scenario (common with lean production) versus a batch-style manufacturing scenario. The focus group reported that several green manufacturing metrics were more positive in lean manufacturing than batch-style manufacturing:

- Air pollution was lower in a cellular manufacturing scenario since exhaust and power consumption was less.

- Employee's safety and health were better with an optimized plant layout.

- Exposure to dangerous material was reduced by eliminating unneeded material transfers.

Teresko (2004) made the connection between green manufacturing and the lean movement in his research into Bill McDonough's book "Cradle to Cradle". Teresko recites McDonough's statements that the goal of lean, when applied to a manufacturing facilities layout, is to "shrink-wrap a structure around an optimized process; including the entire external commercial environment in the optimized process, integrating all the manufacturing flows from global to national to submicroscopic levels". Teresko pointed to McDonough's success in the construction of Ford Motor Companies new, revitalized Rouge Center with "its innovations at the brown field site which included a 10-acre roof planted with sedum sod and water-permeable paving" throughout the complex. Much like Bergmiller and McWright's study, Teresko identified that lean seems to transcend green. 


\section{Lean and green implementation strategies}

Green has a standardized process by which implementation is carried out and lean does not. Traditionally, lean implementation has been accomplished through an analysis of the shortcomings of an existing process, implementation of a revised process, and subsequent Plan-Do-Check-Assess (PDCA) cycles (Dennis, 2007; Massei and Simeoni, 2003). Rother and Shook (2003) give a high-level overview of how to carry out a lean transformation as a five-step process as seen in Table 3 as well as a complex value stream mapping process that identifies current and future states. PDCA cycles are usually performed after lean implementation to further improve the future state value stream.

\begin{tabular}{|l|l|}
\hline & Steps \\
\hline 1 & Find a change agent/champion \\
\hline 2 & Find a sensei (a teacher whose learning you can borrow). \\
\hline 3 & Seize (or create) a crisis to motivate action across your firm. \\
\hline 4 & Map the entire value stream for all of your product families. \\
\hline 5 & Pick something important and get started removing waste. \\
\hline
\end{tabular}

Table 3. "Rother and Shook's (2003) five step process of a lean".

Much like lean, green manufacturing implementation is largely dependent on PDCA for deployment and assessment (Maynard, 2007). According to Bergmiller and McWright (2009) "implementing an environmental management system (EMS) is a process by which an organization's management identifies regulated and unregulated environmental aspects and impacts of its operations, assesses current performance, and develops targets and plans to achieve both significant and incremental environmental improvements." In a 1997 study, Briscoe, Marcus, Maxwell, and Rothenberg identified that $80 \%$ of Fortune 500 firms had written environmental statements, or the "Plan" in PDCA. The mid-1990's is identified as the start of the green manufacturing movement (Haworth, 2009).

While lean and green manufacturing strategies share similar implementation strategies, they differ in the standards to which implementation is evaluated. According to ISO 14001 (2009), green's “ISO 14001 is a standard for environmental management systems to be implemented in any business, regardless of size, location or income. The aim of the standard is to reduce the environmental footprint of a business and to decrease the pollution and waste a business produces." The main topic areas of the ISO 14001 standard are as follows (Maynard, 2007): 
1. Scope

2. Normative References

3. Definitions

4. Environmental Management System Requirements

4.1 General Requirements

4.2 Environmental Policy

4.3 Planning

4.4 Implementation \& Operation

4.5 Checking/Corrective Action

4.6 Management Review

Steps 4.3 through 4.6 clearly demonstrate the dependency of ISO 14001 on the PDCA cycle for both administration and continuous evaluation of the standard throughout the implementation cycle.

Lean manufacturing does not have a universally accepted standard for evaluation. Lean's fundamental principles developed by Toyota are universally accepted but commonly adapted to each organization or industry. Notable examples of these transformations are by Ford Motor Company (the Ford Production System), WalMart and Southwest Airlines.

In summary, lean and green manufacturing have similar implementation strategies but distinctly different methods by which their respective implementations are evaluated. While the implementation strategies of lean, the do's and don'ts, have been largely studied (Womack, Jones, 2003), the implementation's evaluation method is much less standardized that that of green manufacturing's ISO 14001.

\section{Supplementing lean implementation tools}

The classical deployment of lean's tools such as standardized work, value stream mapping, visual control, Kaizen, etc are ways to "work around certain types of problems but they do not solve them for you or always highlight the underlying cause of many types of problems." (Lean Manufacturing, 2009).

In the last several years, much research concerning applying techniques such as linear and non-linear programming, and discrete event simulation (DES) as lean tools has been conducted. Multiple authors cite the significant (positive) impact the application of these tools can have in conjunction with the more traditional tools as 
developed by Toyota (Marvel \& Standridge, 2009; Maynard, 2007). Curry (2007) described how DES is used to "allow one to visually see and measure how processes perform over time, including materials, information and financial flows, and how probabilistic variables impact them". Additionally, Curry stated how DES is an extremely valuable compliment to value stream mapping (VSM) because VSM is inherently non-analytical and static in nature. DES on the other hand is dynamic in nature and allows for experimentation on VSM-developed future state scenarios.

Along similar lines, Perez, Choudhuri and Standridge (2008) developed an integer programming model and solver in order to optimally select suppliers for a production activity based on any number of factors. It was determined that the model could not only reduce costs but "contribute to improving quality and simplifying supply chain management". Since cost reductions and simplification are core objectives of lean, the positive implications for such quantitative analysis tools such as DES and optimization for lean companies can be significant.

\section{A case for quantitative analysis}

The use of lean's classical tools alone is inherently wasteful since they can not sufficiently validate and explore various proposed changes to a future state value stream (Curry, 2007; Marvel \& Standridge, 2009). Other authors describe how the limitations of value stream mapping can be overcome using DES (Abdulmalek \& Rajgopal, 2006; Lian \& Van Landeghem, 2007). The application of techniques like DES and mathematical optimization provide much more help in assuring waste avoidance before a lean implementation event.

Curry (2007) describes how a laminated plastic manufacturer had performed value stream mapping, implemented $5 \mathrm{~S}$ strategies in all of its work centers and held Kaizen events in order to identify possible solutions to convert its process from batch-and-queue to flow processing. The VSM's had resulted in a laundry list of unknowns, especially reasonable estimates of key variables such as set-up time and machine downtime (reliability) as well as the effects on overall performance measures. The development of a DES model actually provided a structure for data collection for some of the VSM's missing information. The manufacturer's analysts were able to develop "a range of likely values through a combination of limited sampling and input from factory floor staff to begin using simulation for bottleneck 
or constraint verification". Experimentation on the developed model led the analysts to explore/discuss/re-test different production scenarios that were largely non-intuitive. The analysts exposed problems that otherwise probably would not have been found without DES. Clearly, for the laminated plastic manufacturer, the traditional lean tools alone were of significant value but the complimentary use of DES helped them implement lean strategies more effectively.

Without DES, would the manufacturer have eventually exposed the problems found during DES and, if they did, at what cost? Perhaps they would have pushed ahead with implementation of the flow process. Theoretically, several things might have happened:

- They may have decided to move a machine or group of machines in a work cell to a new configuration

- They may have decided to alter inventory levels

- They may have decided to alter the number of machines in a work cell

While the aforementioned list is by no means exhaustive, it serves to exemplify the waste that can be generated if a future state value stream is implemented without sufficient verification and validation procedures. Traditional lean results can be more effectively implemented with support from mathematical optimization and DES, and, as a result, these techniques promote sustainability.

\section{Case study}

Grand Rapids Chair Company is a small furniture production company located in Grand Rapids, Michigan. Growing gross sales by over 10\% each year for over a decade, strategically shifting its production model from a reseller to a manufacturer and the construction of a new facility in 2005 have presented many challenges since the company's incorporation in 1995.

The company produces chairs and tables for contract and educational furniture markets: tubular steel, wooden, plywood or aluminum chairs; plastic, wood or laminated tables; and cast iron, steel or aluminum table bases. In order to produce these products, the company utilizes a constant work in-process (CONWIP, 2009) 
operational model. The production is broken into two distinct value streams, the wooden value stream and the steel value stream as seen in Figure 1.

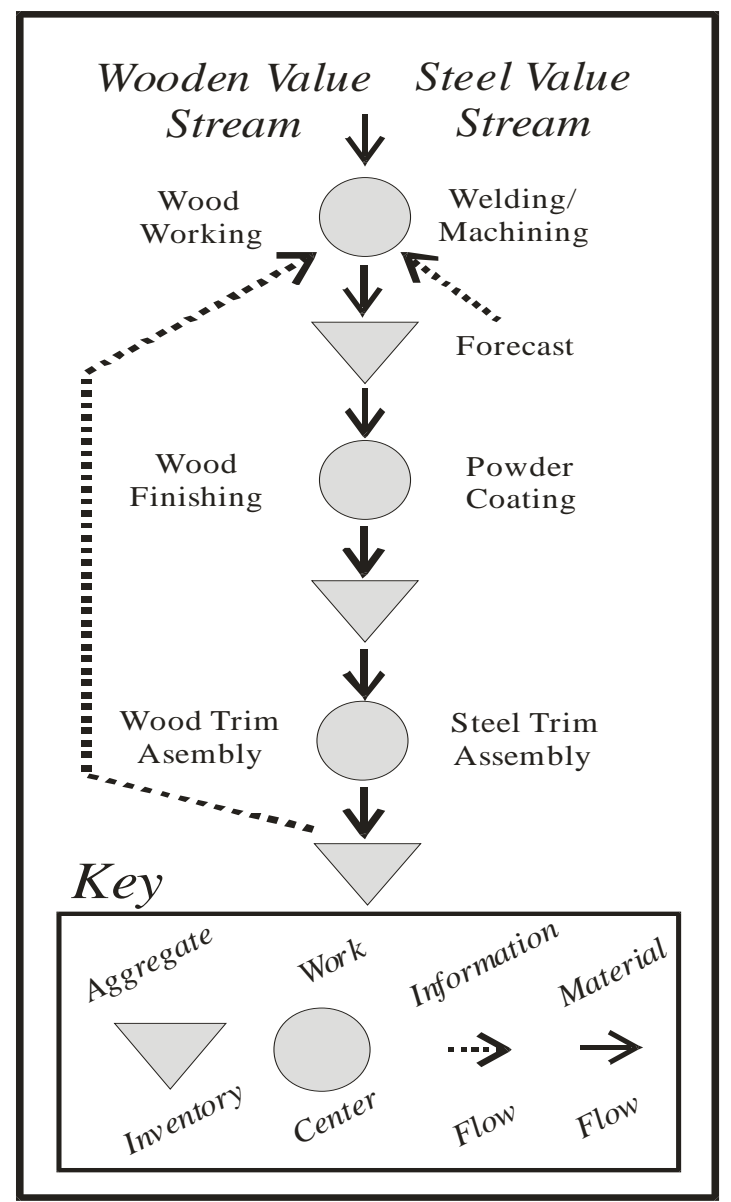

Figure 1. "The two value stream CONWIP production model".

In 2004, the company faced adversity like none other it had ever faced. The loss of its largest customer month's earlier, increased pressure for lead-time reductions by existing customers and growing quality expectations mandated change. Lean manufacturing was the model of choice because of the sensei (Rother and Shook, 2003) contracted by the company's executive team. Lean's systematic elimination of waste helped the company become more operationally stable and helped the company develop a culture of PDCA through its value stream management approach.

The following sections are three different case study examples from lean and green projects carried out by the company. The case study examples identify how lean and green manufacturing strategies have helped the company produce more 
efficient work cells, reduce waste and increase profitability. The complimentary use of DES and mathematical optimization is emphasized.

\subsection{Case study example: 2007-2008 “RCELL”}

The following case study example demonstrates the significant impact that DES can have on the design, planning, construction, implementation and operation of a lean workcell. The deployment of DES in the workcell's design phase helped reduce several lean and green wastes listed in Tables 1 and 2 .

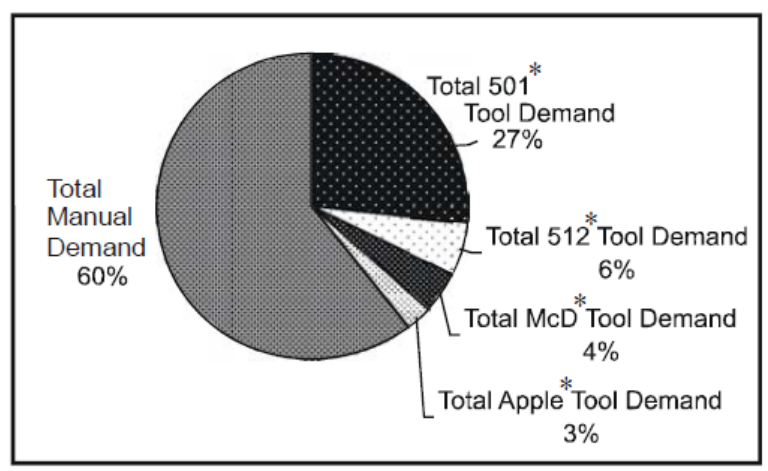

Figure 2. "2007 Steel Value Stream Demand Distributions".

After approximately twelve years of steady growth, customer demand had allowed a strategic shift in the company's production operational model. Four different product groups represented approximately $40 \%$ of the company's demand as shown in Figure 2. VSM and Shingo Assessment procedures, as were described by Robinson (1990) and Shingo and Dillon (1989), showed that these products could be produced in a workcell much more efficiently than they could in the company's traditional job-shop (functional) layout. Accordingly, the integration of a new workcell centered on a robotic welding machine was proposed and accepted in 2007. Called "RCELL", the workcell consists of a series of oxy-acetylene brazing stations, a grinding station and a robotic welding machine. An overhead conveyor system delivers gas-metal arc welded assemblies from the robotic welding machine to four oxy-acetylene brazing stations. The oxy-acetylene brazing stations are working in parallel and are the final workstations in the RCELL process before they are delivered to the workcell's downstream customer. The value stream map (Figure 3) provides further information regarding the workcell's material and informational flow systems. 


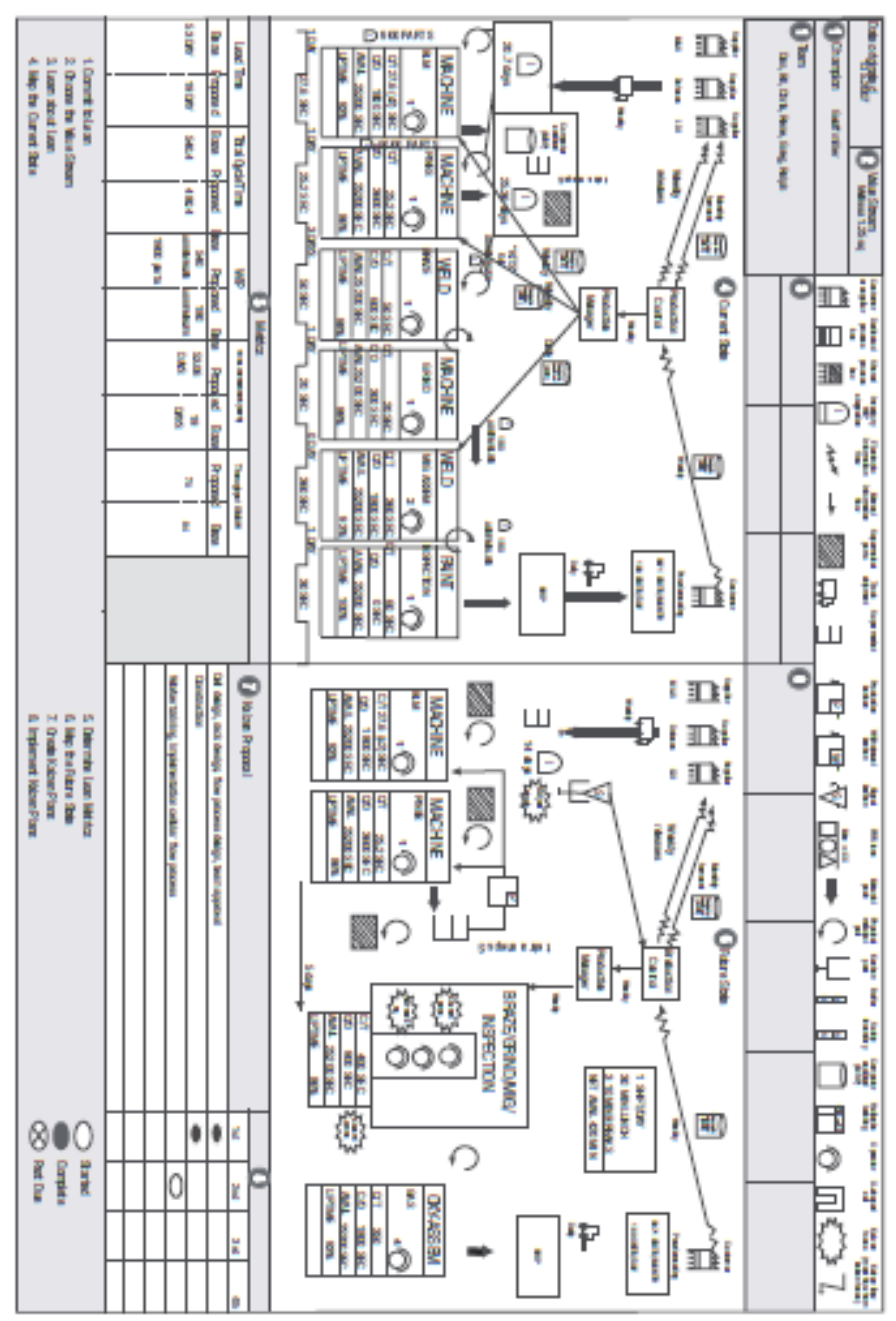

Figure 3. "2007 welding cell value stream map".

The RCELL project deployed various lean tools such as standardized work, Kanban, $5 S$ and quick-changeover (SMED) to eliminate various forms of waste. Other lean tools such as process mapping, activity charting, cycle time measurement, line balancing and layout planning determined that the RCELL could produce thirty-five units per hour while the non-cellular layout could achieve approximately twentyone units per hour. 


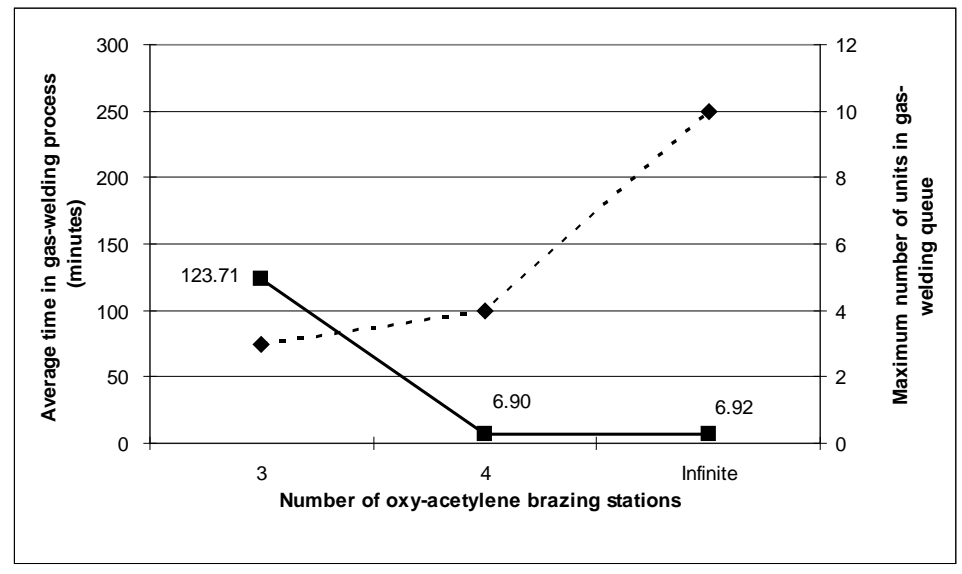

Figure 4. "Relationship between processing time and the number of oxy-acetylene brazing stations".

DES helped validate that the workcell's design was conducive to one-piece flow or at least micro-batch processing. Simulation experiments involved setting a CONWIP limit equal to the number of oxy-acetylene brazing stations in the workcell, either $1,2,3$, or 4 as well as infinite. The results presented in Table 4 and Figure 4 suggested exponential decay in the time delay due to the CONWIP limit for values less than 4 workstations. For values of 4 workstations or greater, the average delay time remained approximately constant. These results are consistent with the behavior of a CONWIP system. Values of the CONWIP limit that are less than 4 constrain the productivity of the system. The smallest values of the CONWIP limit greater than or equal to the number of stations that does not constrain productivity is ideal. Table 4 validates that a CONWIP value greater than 4 , the number of brazing stations, would not increase productivity; the DES experiments returned the same throughput values for both the 4 and infinite CONWIP value scenarios.

\begin{tabular}{|c|c|c|c|}
\hline $\begin{array}{c}\text { Number of Oxy- } \\
\text { Acetylene Brazing } \\
\text { Workstations }\end{array}$ & $\begin{array}{c}\text { Average Unit Time in } \\
\text { Oxy-Acetylene } \\
\text { Brazing Process } \\
\text { (Minutes) }\end{array}$ & $\begin{array}{c}\text { Maximum Number of } \\
\text { Units in Oxy-Acetylene } \\
\text { Workstation Queue }\end{array}$ & $\begin{array}{c}\text { Throughput (Average } \\
\text { Units Produced by } \\
\text { Workcell Over Simulation } \\
\text { Period) }\end{array}$ \\
\hline 1 & 789.87 & 1 & 389 \\
\hline 2 & 455.78 & 2 & 778 \\
\hline 3 & 123.71 & 3 & 1163 \\
\hline 4 & 6.90 & 4 & 1299 \\
\hline Infinite & 6.92 & 10 & 1299 \\
\hline
\end{tabular}

Table 4. "Relationship between processing time and the number of oxy-acetylene brazing stations". 
The simulation model and associated experiments helped identify that there was no advantage to continuous production of gas-metal arc-welded assemblies from the robotic welding machine. Throughput only increased as long as the oxy-acetylene brazing stations were consistently adding value. Therefore, the standardized work created by the company detailed how other cell workers could help maintain workcell flow by assisting the oxy-acetylene brazing operators, effectively standardizing teamwork amongst the RCELL's workers.

The use of lean tools, complimented by an advanced technique (DES), helped the company decrease inventories and processing times as well as total lead-time from the current state to the future state as seen in the value stream map (Figure 3). Several non-intuitive situations (CONWIP limit and its relationship to lead time) were explored and verified by DES. Clearly, the workcell's design was greatly influenced by both lean and DES.

Without lean and DES, what could have been? Several possible scenarios could have occurred, including the following:

- Underproduction: suppose only two or three oxy-acetylene workstations had been planned at the start of the workcell project. Figure 4 shows that the company would have had to quickly either re-arrange its workcell or risk not meeting customer demand

- Overproduction: without DES it would have been very difficult to properly estimate the CONWIP limit; had DES not validated the CONWIP limit before the final implementation of the cell perhaps the footprint of the WIP waiting to be processed by the cell would have been larger than necessary

These possible scenarios violate each of the eight forms of lean waste (Table 1 ). Each scenario would have required significant energy cost either in the rework of the workcell $(A)$ or additional energy cost in the support of a larger workcell than what was really needed (B). DES can greatly reduce the risk of error when implementing a value stream's future state. These errors can be costly and inject significant waste into the implementation, which shows that a lean implementation can be potentially unsustainable. 


\subsection{Case study example: 2008 recycling project}

Based on a 2008 Kaizen event, this example demonstrates that some of the results of lean projects are inherently green and gives further support of the many parallels found between lean and green manufacturing.

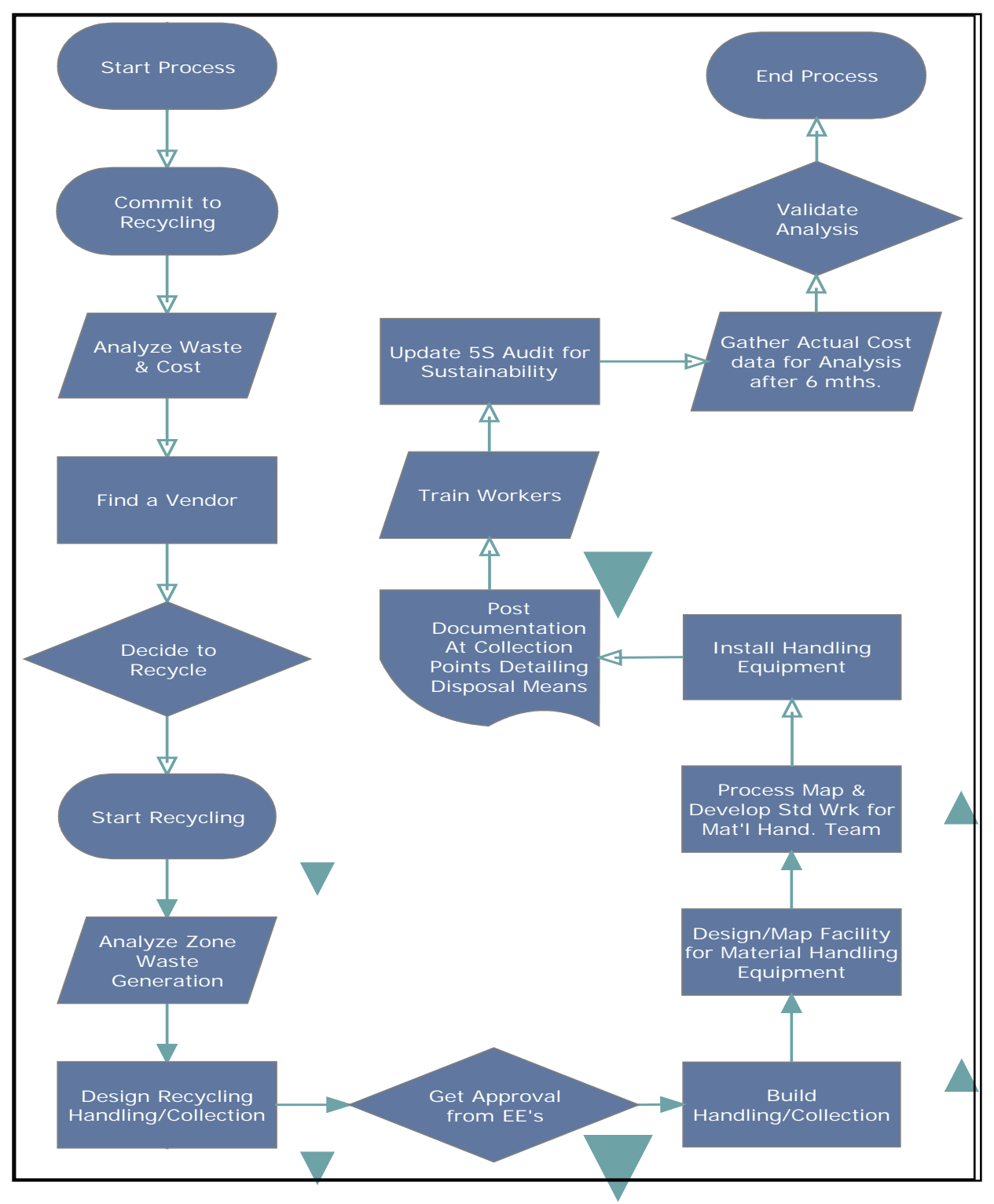

Figure 5. "Process map for development of recycling program".

Lean's focus on stable and standardized processes led Grand Rapids Chair Company to begin formalized documentation of not only value-added but nonvalue-added, necessary work processes. In December 2006, the company 
completed the documentation of its environmental plan, which outlined various processes such as liquid/solid waste disposal and recycling.

In the fall of 2008, a routine Kaizen event was started by the company's operations manager at the suggestion of the company's president. The president suggested "if you want to see what is wrong in your factory, look at your trash". As a result, the operations manager mandated that all solid waste be collected in a central location prior to disposal each morning. The operations manager and several other system managers began a process of sifting and sorting through up to eight- 0.88 cubic yard hoppers each morning after their daily start-up meeting for approximately twenty working days. A brief analysis led to the development of a process map for the development of a robust recycling program (Figure 5).

The Kaizen and subsequent cost analysis (Table 5) identified that approximately 1.75 dumpsters per day ( 1.54 cubic yards) could be diverted from the company's solid waste stream to recycling. The annual estimate for diversion of solid waste was approximately 220 cubic yards or $5.5-40$ cubic yard dumpsters.

\begin{tabular}{|c|c|}
\hline Concept & Cost \\
\hline Savings from recycling & $\$ 13,803.34$ \\
\hline Trucking cost & $\$ 2,360.17$ \\
\hline Sorting cost at recycling center & $\$ 4,392.77$ \\
\hline Handling cost & $\$ 5,100.00$ \\
\hline Total savings from recycling (Loss) & $\$ 1,950.00$ \\
\hline
\end{tabular}

Table 5. "Costs of recycling".

Similar to the RCELL Project, the Recycling Project highlights the connection between lean and sustainability. Lean's foundation in stability and standardization, empowerment of workers and continuous evaluation of process (Kaizen) led the company to disregard 'status quo' and achieve a greater level of waste elimination-in this case real "waste".

\subsection{Case study example: 2008-9 optimized supplier selection using a total supplier cost analysis model}

The following case study example shows the complementary nature of optimization with lean and green manufacturing. Optimization, like DES, plays an important role in reducing cost and finding non-intuitive approaches to create and deliver value to customers that may not be possible using lean and green tools alone (Chang, Chen, 2006). Optimization's role as an analysis technique is well documented, 
particularly as a tool in developing lean supply chains (Chang $\&$ Chen, 2006; Perez, Choudhuri, \& Standridge, 2008; Choudhuri, Miller, \& Standridge, 2009; Suresh \& Kesayan, 2008).

Grand Rapids Chair Company has applied optimization techniques recently as a tool to decrease the number of suppliers and improve quality, service level, price and other key measures as well as generally simplifying its supply chain. Recently, the company developed a supplier selection model for its table component product line utilizing a concept called Total Supply Cost (TSC) (Perez et al., 2009). The table products produced by Grand Rapids Chair had 203 different components. Several of these had multiple potential suppliers some of whom offered reduced lead times and discounts based on annual volume. An analyst discovered substantial freight savings through transportation consolidation from some of the suppliers. Substantial savings could be achieved if the number of suppliers was reduced.

The company's TSC model is based on the multi-faceted supplier selection model (MASS) (Perez et al., 2009), which includes tooling and annual material, shipping, holding and quality costs associated with part supply from a particular vendor. A simplified version of the TSC model was employed. Equations 1 - 3 show the components of the objective function.

Determining the estimated annual cost for each component was necessary for each supplier $\mathrm{i}$ and part $\mathrm{j}$ :

$$
\min \sum_{i=1}^{n} \sum_{j=1}^{n} D_{i j} C_{i j}
$$

$D_{i j}=$ annual demand, $C_{i j}=$ cost for part.

The next step was to determine the total shipping cost reduction possible if the freight consolidation opportunity is taken advantage of by mandating weekly shipments from the suppliers that have variable shipping cost (two of the product line's four suppliers had variable shipping costs). This was calculated as follows:

$$
\sum_{j=1}^{n} D_{i j} W_{j} X_{i} \quad \text { for } i=1,2
$$


$W_{j}=$ weight per part, $X_{i}=$ fraction of shipping cost saved.

The last step was to determine the savings of consolidation to Supplier 2 if a $2 \%$ annual discount is taken on the total purchases over the entire year. One supplier had offered substantial discounts if orders were increased. This was expressed as follows (Equation 3):

$$
\sum_{j=1}^{n} D_{2 j} C_{2 j} *(0.02)
$$

Thus the objective function to be minimized is the following:

$$
\begin{aligned}
& \min \sum_{i=1}^{n} \sum_{j=1}^{n} D_{i j} C_{i j}-\sum_{j=1}^{n} D_{i j} W_{i} X_{i}-\sum_{j=1}^{n} D_{2 j} C_{2 j} *(0.02) \\
& \ni \\
& i=1,4 \\
& j=1,203
\end{aligned}
$$

and is subject to the constraint that each part must be obtained from exactly one supplier.

The MATLAB R2008B (version 7.7 student edition) software was used to find the optimal distribution of the 203 different parts amongst the company's four different suppliers. The model identified the opportunity for over $\$ 100,000$ in annual cost savings, much of which was related to transportation. These opportunities directly related to several of the nine forms of waste from green manufacturing (Table 2) such as clean air, energy use and solid waste generation. Less need for transportation (larger, consolidated 'bulk' shipments) meant less frequent truck pick-ups to the factory and less packaging materials used by the factory's supply chain. Furthermore, the table component product line's suppliers could be consolidated to three.

Similarly to the previous case study examples, the optimized supplier selection using a total supplier cost analysis model reaffirms parallels found between lean and green manufacturing. Lean's traditional tools combined with advanced techniques such as mathematical optimization can greatly reduce an organization's environmental impact. 


\section{Conclusion}

The case study provided validation evidence for the two premises. Each of the projects showed that Lean transcends green. In the RCELL study, the use of DES to enhance Lean avoided over production or under production, thus avoiding unnecessary energy consumption. The recycling project resulted from a Lean process Kaizen event concerning the solid waste disposal process and led to the recycling of a significant amount of material previously disposed of as waste. In the optimized supplier selection project, the Lean concept of reducing the number of suppliers was addressed using mathematical programming that resulted in a consolidation to fewer suppliers, reducing the number of miles driven and thus making the supply activity more green and sustainable.

The RCELL project and the optimized supplier selection project showed that the use of quantitative analysis tools makes a lean transformation more precise and thus leaner. The RCELL study used DES to validate the proposed future state of the workcell. This added precision minimized the lead time from the current state to the future state, reducing waste by decreasing inventories and processing time as well as avoiding future redesigns due to over production or under production. Using mathematical optimization to select the company's suppliers resulted in a significant cost saving with respect to transportation and consolidation to fewer suppliers in one step, thus minimizing the time to realize these savings.

Thus, the effectiveness and validity of both premises for Grand Rapids Chair have been demonstrated.

\section{References}

Abdulmalek, F. A., \& Rajgopal, J. (2007). Analyzing the Benefits of Lean Manufacturing and Value Stream Mapping Via Simulation: A Process Sector Case Study. International J ournal of Production Economics, 107(1), 223-236.

doi: 10.1016/j.ijpe.2006.09.009

Allwood, J. (2005). Sustainable Manufacturing Seminar Series. Retrieved December 26, 2009, from

http://www. ifm.eng.cam.ac.uk/sustainability/seminar/documents/050216lo.pdf. 
Angel, L., \& Robert K. (1999). Integrating Environmental Issues into the Mainstream: An Agenda for Research in Operations Management. Journal of Operations Management, 17.

Bergman, L., Hermann, C., Stehr, J., \& Sebastian T. (2007). An Environmental Perspective on Lean Production. The 41st CIRP Conference on manufacturing Systems, 2008.

Bergmiller, G., \& McWright, P. (2009). Lean Manufacturers' Transcendence to Green Manufacturing. Proceedings of the Industrial Engineering Research Conference, May 30 - June 3, Miami, FL.

Briscoe, F., Marcus, A., Maxwell, J., \& Rothenberg, S. (1997). Green Schemes: Corporate Environmental Strategies and Their Implementation. California Management Review, 39(3).

Chang, P., \& Chen, S., (2006). A Mathematical Programming Approach to Supply Chain Models with Fuzzy Parameters, Engineering Optimization, Taylor and Francis.

Choudhuri, S., Miller, G., \& Standridge, S. (2009). Real Life Implications for Project Based Learning. ASEE North Central Section Conference April 3-4, 2009. Retrieved December 26, 2009, from

http://claymore.engineer.gvsu.edu/ocs/index.php/aseencs2009/aseencs2009/pap er/view/115/61.

"CONWIP" (2009). Wikipedia, The Free Encyclopedia. Retrieved December $26^{\text {th }}$, 2009, from http://en.wikipedia.org/wiki/ CONWIP.

Curry, JJ. (2007). A Lean Analysis Methodology Using Simulation. Society of Manufacturing Engineers (SME) Technical Paper. Retrieved December 26, 2009, from http://www.sme.org/cgi-bin/get-item.pl?TP07PUB5\&2\&SME

Dennis, P. (2007). Getting the Right Things Done. The Lean Enterprise Institute, Brookline, MA.

Fishman, G. (2001). Discrete-Event Simulation: Modeling, Programming, and Analysis. Springer-Verlag, New York, NY. 
Groover, M. (2007). Worksystems and the Methods, Measurement and Management of Work. Pearson Prentice Hall.

Haworth, D. (2009). Sustainability. Forest Products Society, Great Lakes Region 2009 Seminar presentation, May 12, 2009 Crowne Plaza, Grand Rapids, MI.

"History of the Green Movement" (2009). Wikipedia, The Free Encyclopedia. Retrieved December $26^{\text {th }}, 2009$, from http://en.wikipedia.org/wiki/green_movement

"ISO 14000" (2009). Wikipedia, The Free Encyclopedia. Retrieved December 26, 2009, from http://en.wikipedia.org/wiki/ISO_14000

"Lean Manufacturing" (2009). Wikipedia, The Free Encyclopedia. Retrieved December $26^{\text {th }}, 2009$, from http://en.wikipedia.org/wiki/lean_manufacturing

Lian, Y. H., \& Van Landeghem, H. (2007). Analysing the Effects of Lean Manufacturing using a Value Stream Mapping-Based Simulation Generator. International J ournal of Production Research, 45(13), 3037-3058. doi: $10.1080 / 00207540600791590$

Liker, J. (2004). The Toyota Way. Madison, WI. McGraw-Hill.

Massei, M., \& Simeoni, S. (2003). Application of Simulation to Small Enterprise Management and Logistics. Society for Modeling and Simulation International Conference.

Marvel, J., \& Standridge, C. (2009). A Simulation-Enhanced Lean Design Process. Journal of Industrial Engineering and Management. 2 (1), 90-113. doi: 10.3926/jiem.2009.v2n1.90-113

Maynard, H. (2007). Industrial Engineering Handbook-5 ${ }^{\text {th }}$ Edition. McGraw-Hill, edited by Kjell B. Zandin.

Miller, G., Rahman, A., \& Choudhuri, S. (2008). Systematic Validation of Process Automation and Cellular Layout in an Existing Furniture Production Line, International Conference on Agile Manufacturing, Western Michigan University, July 16-18. 
Perez, E., Choudhuri, S., \& Standridge, C. (2008). Application of Genetic Algorithm in Supplier Consolidation using Multifaceted Selection Model. Journal of Advanced Manufacturing Systems, 11(1), 31-38.

Robinson, C. (1990). Modern Approaches to Manufacturing Improvement: The Shingo System. Productivity Press

Rother, M., \& Shook J. (2003). Learning to See: Value Stream Mapping to Create Value and Eliminate Muda. Brookline, MA. The Lean Enterprise Institute Brookline, MA.

Sawhney, R., Teparakul, P., Aruna, B., \& Li, X. (2007). En-lean: a framework to align lean and green manufacturing in the metal cutting supply chain. Society for Modeling and Simulation International.

Shah, R., \& Ward, P. (2002). Lean manufacturing: Context, Practice Bundles and Performance. J ournal of Operations Management, 21 (2), 129.

doi: $10.1016 / \mathrm{S0272-6963(02)00108-0}$

Shingo, S., \& Dillion, A. (1989). A Study of the Toyota Production System: From an Industrial Engineering Viewpoint (Produce What Is Needed, When It's Needed). Productivity Press.

"Society of Manufacturing Engineers" (2009). SME website. Retrieved December 26, 2009, from http://www.sme.org/

Suresh, P. \& Kesavan, R. (2008). Integration of GA with SA Techniques to Design an Optimal Supply Chain Distribution Network. International Journal of Supply Chain Management, 5(2).

Teresko, J. (2004). Lean, Green and Smart. Industry Week, May 5, 2004.

"The Shingo Prize for Operational Excellence" (2009). Utah State University. Retrieved December 26, 2009, from http://www.shingoprize.org/

Wei Huang, V., Kulkarni, J., \& Swaminathan, M. (2004). Optimal EOQ for Announced Price Increases in Infinite Horizon. Operations Research, 51(2), 336339. doi: 10.1287/opre.51.2.336.12785 
Womack, J., \& Jones, D. (2003). Lean Thinking. New York, NY. Free Press.

(c) Journal of Industrial Engineering and Management, 2010 (www.jiem.org)

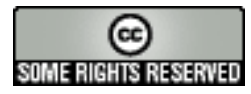

Article's contents are provided on a Attribution-Non Commercial 3.0 Creative commons license. Readers are allowed to copy, distribute and communicate article's contents, provided the author's and Journal of Industrial Engineering and Management's names are included. It must not be used for commercial purposes. To see the complete license contents, please visit http://creativecommons.org/licenses/by-nc/3.0/. 